\title{
Bankers on boards as corporate governance mechanism: evidence from Poland
}

\author{
Agnieszka Slomka-Golebiowska
}

Published online: 9 November 2012

(C) The Author(s) 2012. This article is published with open access at Springerlink.com

\begin{abstract}
This paper examines whether a bank exercises a monitoring role when a banker is represented on a firm's board. Bank monitoring reduces information asymmetries, and hence lessens firm's financial constraints-phenomenon frequently measured by investment-cash flow sensitivity in the sample of all nonfinancial companies listed during 1999-2002 on the Polish stock exchange. I find that firms with a banker on the board rely more heavily on bank loans than on internal capital in their investment activities. In contrast, firms with no banker on the board finance to a larger extent their investment with internal capital than with credit. However, firms with the bank-lender representation on the board are almost as much financially constrained as firms without a bank-lender representative on the board. Hence, the presence of bankers on boards is not associated with bank monitoring. They rather promote their employer's business. The findings show that investment of firms with a banker on the board is less sensitive to cash flow than investment of firms without bank representatives on the board. This result suggests that bankers on the board provide financial expertise that help those firm to reduce financial constraints.
\end{abstract}

Keywords Corporate governance $\cdot$ Board of directors - Relationship banking and transition economies

JEL Classification $\mathrm{G} 32 \cdot \mathrm{G} 34 \cdot \mathrm{P} 34$

\footnotetext{
A. Slomka-Golebiowska ( $\square)$

Warsaw School of Economics, 164 Al. Niepodleglosci, 02-554 Warsaw, Poland

e-mail: aslomka@sgh.waw.pl
} 


\section{Introduction}

When a transition process began in post-communist economies in Central and Eastern Europe in the early 90s, the state had withdrawn from corporate governance and a gap was revealed. Since then, corporate governance structures that are typical of a market economy have been slowly emerging. Initially, banks were expected to play a more important role as the banking sector was far more developed than capital market. The latter was arising from scratch as well as institutions that support it. After almost two decades since the transition started bank credit is far more significant source of external corporate financing compared to capital market.

Banks as a significant provider of firm's external capital want to obtain the returns on their investments. The power of creditors comes from bankruptcy proceedings when they take control over debtor and its assets that served as collateral, if the firm is not capable to repay the loan. Collaterals and threat of bankruptcy may be regarded as passive modes of bank monitoring. Banks may also actively control indebted firms and their investment decisions through relationship banking or sitting on the firm's board. Additionally, in many countries, banks are entitled to hold equity as well as debt of the firms they invest in, or alternatively vote the equity of other investors. Hence, they have various possibilities to induce debtor's managers to use credit according to the terms of contract. Bank monitoring enables banks to gather inside information about a firm that are not accessible to other stakeholders. The closer relationship with their corporate clients banks maintain, the more successful they are in reducing information asymmetries between themselves and borrowers. By reducing information asymmetries banks are able to lessen firm's financial constraints.

Information asymmetries are central to the role of banks in corporate governance (Akerlof 1970; Stiglitz and Weiss 1981) as they hinder access to external financing even in market equilibrium and hence lead to credit rationing. Then, firm investment depends on availability of internal capital. Information asymmetries problem makes the cost of external financing higher than internal one. In consequence, firm's managers always prefer less expensive internal capital to external one (Myers and Majluf 1984). Diamond (1984) argues that close relationship with a bank-creditor is capable of lessening information asymmetries, thus benefiting not only lender, but also borrower through reducing both credit rationing and the cost of external financing. Others indicate that close relationship with banks may generate lender's rent extraction from the borrower, because the latter is informationally captured by the former and, hence, not necessarily bring about the previously envisaged reduction in credit constraints for borrowers (Sharpe 1990; Rajan 1992; Kracaw and Zenner 1998). The empirical evidence is scarce and conflicting for Japan (Weinstein and Yafeh 1998) and for Germany (Elsas and Krahnen 1998).

The aim of the study is to examine whether banks in Poland exercise monitoring role, when a banker is represented on the firm's board and hence firms are less financially constrained in their investment decisions. Empirical literature confirms that credit contract allows for an efficient monitoring of corporate debtors through reducing information asymmetries. Firms that maintain a close bank relationship tend to be less financially constrained in their business activities than firms without such 
ties. For example, Hoshi et al. (1991) find that large Japanese corporations that have close financial ties to large banks, that serve as their primary source of external finance, face lesser financial constraints than firms without such a relationship with banks. Using data on the same group of firms for a later period of time, when liberalization of financial markets in Japan occurred, McGuire (2003) shows that difference in financial constraints between the two groups of firms is much smaller as access to other than bank loans sources of external financing, in particular bonds becomes available. Van Ees and Garretsen (1994) for Dutch large companies as well as Elston (1996) and Harm (1996) reveal similar results for German large corporations. According to Houston and James (2001) bank-dependent firms in the US are less financially constrained in their investment activities than other firms that have credit relationship with a number of banks or are using bond financing. The difference between those two groups of firms is significant when firms make relatively small investment $(<25 \%$ of their capital stock). The access to bank financing for US firms depends on the size of planned investment, and hence the mode of corporate governance depends for the level of investment outlays. That is a consequence of legal solutions binding in the US such as equitable subordination and lender liability limit. Their findings suggest that the role of banks in corporate control is determined very much by the institutional settings, in particular regulatory regime.

Over the last 20 years of the transition from a centrally planned to a market economy Poland reached a great progress in creating institutional conditions for banks' involvement in corporate control. However, there is little empirical evidence of the bank monitoring. Most studies were conducted for developed countries. Few papers are available on emerging markets, mostly Korea (Ferri et al. 2001; Bae et al. 2002; Kim et al. 2002). This study is the first attempt to address the issue for a transition country. The reminder of this paper is organized as follows. Section two, preceded by introduction, reviews why bankers are on the boards and whether their presence leads to lessening firm's financial constraints. In the third section the relevant institutional environment with regard to bank-firm relation in Poland as well as methodology and data are explained. Fourth section discusses empirical results and selectivity bias. In the last one conclusions and future research agenda are presented.

\section{Bankers on boards and firm's financial constraints}

Recent literature has suggested that the presence of bankers the board brings several benefits for firms (Kroszner and Strahan 2001; Byrd and Mizruchi 2005; Dittmann et al. 2009). First, bankers may provide financial or investment expertise, in particular if a bank acquired specific knowledge through lending to many firms from a certain industry (Mace 1971; Lorsch and MacIver 1989). Number of studies provide empirical evidence (Ramirez 1995; Morck and Nakamura 1999; Byrd and Mizruchi 2005; Ciamarra 2006; Dittmann et al. 2009).

Second, a close bank relationship, formalized through board representation, can play a certification role, enabling firms to secure financing from other external sources both creditors as well as equity holders (Fama 1985; Kracaw and Zenner 1998). Some studies show that firms with bankers on the board are more leveraged 
(Booth and Deli 1999), also due to the fact that banks sell more debts to firms where they are represented (Dittmann et al. 2009).

Finally, bankers, while sitting on the debtor's board, can act as monitors, by lessening asymmetric information between the bank and the firm in order to safeguard bank's existing loans or their interest as an equity holder. Their presence improves information flow between the bank and the firm, and hence economizes on the cost of monitoring (Fama 1985) and enables better assessment of firm's creditworthiness (Kracaw and Zenner 1998; Kroszner and Strahan 2001), facilitating loans from represented bank. Williamson (1988) views bank monitoring, formalized through board representation, as superior to loan covenants due to having an access to borrower 's proprietary information and a position to discipline management. The empirical evidence on bank monitoring through the presence of bankers on the board are mixed and are identified for Japan (Kaplan and Minton 1994; Morck and Nakamura 1999), for Germany (Dittmann et al. 2009) as well as for the United States (Gilson 1990; Byrd and Mizruchi 2005). In Japan bankers are appointed to the board to monitor poorly performing firms, while this is not true for American firms. In contrast to Japan and Germany, few bank lenders are represented on the US boards (Kroszner and Strahan 2001). Bankers on the board do not monitor lending relationship (Booth and Deli 1999).

Several studies use liquidity sensitivity of investment approach to find evidence that bankers on the board lessen firm's financial constraints (Van Ees and Garretsen 1994; Harm 1996). Having representation on the board, banks may be provided with greater access to information about their clients' investment opportunities and hence the capital allocation process can be improved. The firm investment will rather depend on the existence of new projects than on the availability of internal funds. Unmonitored firms must align their investment plans to their liquidity. Therefore, investment should be more sensitive to internal capital for firms without bankers on the board than for firms with bank board representation. However, Fohlin (1998) reports, using data on German firms for the period 1905-1913, that the link between firm's financial constraints and bank board representation is unstable.

According to the alternative view, bankers that represent a lender on the board may generate conflict of interests. On one hand, they have incentives to safeguard the interests of creditors, on the other hand as board's member, they are expected to act in the interests of shareholders or the firm. As a consequence, banks may be restrained from firm's monitoring activities unless the benefits can offset potential costs related to the conflict of interest. The latter can be alleviated by country's institutional environment, in particular regulatory regime (Kroszner and Strahan 2001).

\section{Institutional framework, methodology and data}

\subsection{Institutional framework}

The purpose of this section is to provide a brief description of corporate governance framework in a post-communist country based on an example of Poland. When the transition started, there was an urgent need to established a strong mechanism of 
corporate governance, which could effectively replace entrenched managers and actively restructured firms. Since capital market did not exist, banks, as the main external capital provider even in pre-transition time, were expected to take the role in corporate governance in Central and Eastern Europe (Baer and Gray 1996; Dittus and Prowse 1995; Gray and Holle 1996).

The possibility to refuse to roll over credit gives banks a potentially powerful control instrument over enterprises. However, they were not prepared to take the lead. Inexperienced in applying market criteria to their lending decisions banks continued to serve their corporate clients they had a relationship in pre-transition period. The concept of creditworthiness was immensely difficult to implement given that private enterprises had no proven track record, rapid systemic change was already in place as well as there was lack of human resources skilled at assessing a borrower's financial situation. Moreover, an increase in credit cost caused that state enterprises in a good standing ceased financing with bank loans. Only those that were in the difficult financial situation tended to finance themselves with credit (Gomulka 1993). That led to highly concentrated banks' loan portfolios and ultimately to a severe problem of bad debts.

Given the magnitude of bad debts in banking sector that reached $32 \%$ of total credit portfolio in Poland a fundamental bank and enterprise restructuring program was indispensable (EBRD 1999). The main aim of the program was to stabilize the commercial banking sector by resolving of the problem of nonperforming loans. It was related with two other goals. First, credit should go to firms that are able to make payments on existing debts and have perspectives to further develop. Second, banks should have incentives to monitor corporate clients in order to assure themselves credit repayment and return on their investment. The bank-led conciliation agreement that was a special tool available only within the framework of the Bank and Enterprise Restructuring Program enabled to impose on firms a hard budget constraint and build institutional capacity for resolution of financial distress (Gray and Holle 1996). After the restructuring program came to the end banks usually decided to strictly restrict the amount of credit granted to corporate sector and hence their role in corporate control diminished considerably (Pawłowicz 1994, 1995). Despite the acquired expertise in the firm restructuring a close bank relationship, inherited from the centrally planned economy, was loosened and ultimately severe firm's financial constraints have occurred (Konings et al. 2002). Larger information asymmetries since cost of collecting information is higher in transition than in market economies as well as difficulties with enforcing contracts discouraged banks from monitoring firms.

The restructuring was a necessary, but not a sufficient condition for bank to get involved in monitoring firms. Privatization was the strongest guarantee that bank decisions could not be subject to state influence. Nevertheless the process was slow in most of the CEE countries, it enabled banks to transform their function from a passive cashier to an active financial intermediary that were interested in debtor's control in order to get credit repaid. Privatization followed by increased competition contributed to creating healthy commercial banking sector in the countries of CEE after more than a decade of the transition process (EBRD 1999). 
Over the transition time the pace of institutional development increased and necessary institutions were established aiming at improving the protection of the rights of creditors. Among others, a great effort was made to reform insolvency and collateral laws in order to restore credibility of bankruptcy threat in most of the CEE countries. The results are mixed as the laws are very efficient in books, however still the law enforcement requires improvement, in particular with regard to bankruptcy proceedings. In Poland as of 2011, the recovery rate-calculated as amount of cents on the dollar claimants recovered from an insolvent firm, was $31.3 \%$, possible to reached on average within 3 years and the average cost of bankruptcy proceedings was still above average figures for the OECD countries (Doing Business Report 2011). Given the discussions above, one might expect that banks will be interested to actively safeguard their loans and monitor debtors actively through the board representation alleviating firm's financial constraints because they are concerned of low effectiveness of bankruptcy threat or because increased competition in banking sector.

\subsection{Methodology}

In this study the bank monitoring is examined by looking at the effect of bankers on the board on firm's financial constraints in a transition economy. Specifically, the question is addressed whether firms with bankers on the board are less financially constrained compared to those firms without bank presence on the board. Firm's financial constraints are measured by cash flow sensitivity of investment. The approach was developed by Fazzari et al. (1988) and used later to analyzed bankfirm relationships.

In this methodology firms are divided into subsamples based on the criteria, which identify a priori those firms that face financial constraints. I use as a criterion a presence of a banker on firm's supervisory board as an indicator of a close bank relationship. Typically, in the recent studies, duration of firm-bank relationship or a number of creditors are perceived as evidence of close ties with banks (Houston and James 2001; Ongena and Smith 2000).

In this paper, placement of bankers on the board is used as a proxy of close firmbank relationship for the two following reasons. First, institutional reforms in banking sector in Poland caused breaking off credit relations between banks and enterprises imposed upon them within monobank system in a centrally-planned economy. At the beginning of transition a great number of new private banks have begun to operate in Poland, and thus competition enormously increased and next consolidation process in the banking sector commenced. As a consequence, firms were constantly inclined to resign from existing bank relationship and encouraged to look for new lenders.

Second, given severe information asymmetries typical of a transition economy maintaining a close credit relationship may not be sufficient for banks to monitor borrowers. With a banker on the board they can have more extensive knowledge about debtor's financial situation.

Having two subsamples: firms with at least one banker on the board and firms without bank representatives on the board, I look at the cash flow-investment 
sensitivity. Strong and positive correlation between internally generated funds and investment outlays indicates the capital market imperfection due to information asymmetries. This creates preference for cheaper internal capital over more expensive external capital. Firms that find it relatively more costly to rise external financing will demonstrate a greater investment-cash flow sensitivity. When firms with a banker on the board appear significantly less investment-cash flow sensitive than firms without bank board representation, it is regarded as evidence that a close bank relationship with creditors lowers the cost of external financing. It will be consistent with the theory that bank monitoring formalized through sitting on firm's supervisory boards diminishes information asymmetries between lender and borrower.

The equation looks like this:

$$
\text { Iit } / K i(t-1)=\alpha 0+\alpha 1 \mathrm{CFit} / K i(t-1)+\alpha 2 \mathrm{Q} i t+\alpha 3 \mathrm{Xit} / K i(t-1)+\varepsilon i t .
$$

where I denotes investment spending in fix assets of the ith firm in time. Investment (I) is a dependent variable and is calculated as the first difference of gross fixed assets expenditures. Fixed assets include land, property, plant, equipment and patents.

There are two explanatory variables: Tobin Q (Q) and cash flow (CF). X controls for other variables that can determine the size of investment expenditures. The first explanatory variable represents future growth investment opportunities, which is proxied by market-to-book ratio. The second variable, cash flow (CF), is measured as net income plus non-cash costs (e.g. depreciation) minus non cash expenditure. Hence, it is represented by cash flow from operating activities.

In a world with complete information investment could be financed by any combination of internal and external capital (Modigliani and Miller 1958). Investment expenditures would depend only on profitability of firm's investment opportunities. However, in the real world there is always some degree of information asymmetries between a financier and a firm. It leads to a situation when the cost of external capital is higher than internal one. This can significantly reduce firm's investment activities, which then are restricted by the amount of cash flow generated internally.

Recent empirical work suggests that it is necessary to include on the right hand side of the equation an interaction term $(\mathrm{CF} / \mathrm{Kt}-1 * \mathrm{Neg})$ indicating negative cash flow observations. Neg is a dummy variable equals 1, if firm's cash flow is negative, or 0 otherwise. Firms with negative cash flow drive investment down to its lowest possible level, making it unable to respond to further reduction in cash flow (Allayanis and Mozumdar 2004). This reduces the investment-cash flow sensitivity for these observations.

In the above equation I added several control variables (for details see appendix Table 5) to determine the robustness of my results. They are defined as follows. I include production to control for a potential accelerator effect. High level of production may lead to increase capacity in the future, hence more fix assets investment expenditures are necessary. I use revenue from sales (S) as the proxy for production (Abel and Blanchard 1986). 
I also include a few variables that denotes sources of external capital: long-term and short-term bank loans (respectively: LBL and SBL) as well as other long-term and short-term liabilities (correspondingly OLL and OSL). Separating bank loans from other liabilities aims to identify the impact of availability of credit on investment activities. Severe credit rationing may lead to an increase of other liabilities in financing fix assets investments. According to Weller (2001) positive and significant relationship between different variables of external capital and investment expenditures in a transition country indicates that firms operate under a hard budget constraint.

To avoid heteroskedasticity all variables in the model are normalized by the stock of fixed assets at the beginning of the period- $\mathrm{K}(\mathrm{t}-1)$. Further, I add to the equation a dummy variable $(\mathrm{BH})$ that shows the impact of bank's equity holding on firm's investment. It equals 1, if there is at least one bank among firm's shareholders, 0 otherwise.

In order to control for possibilities to acquire external financing for investments from large block shareholders I include a variable indicating concentration of firm ownership structure (OC). It can take values from 1 - the most concentrated firm ownership structure to do 5-the lowest level of concentration. Finally, I add a yearly dummies to weed out macro shocks.

\subsection{Data}

The analysis is based on unique hand-collected panel data set for all non-financial companies that was continuously listed on the Polish stock exchange between 1999 and 2002. The timeframe, for which data was collected, enables to examine the effect of bank monitoring on firm's financial constraints during economic downturn and upturn. The year 1999 represents economic boom as then GDP grew annually by $4.1 \%$. This year together with the first quarter of the year 2000 was also considered to be the most profitable period for the companies listed in Poland. Later the economic growth significantly slowed down. And eventually, year 2001 brought the worst rate of GDP growth in transition period equalled $1 \%$.

I restrict my sample to publicly traded companies for three interrelated reasons. First, data on listed companies is widely disclosed and reliable. Second, these firms are large and hence external financing and corporate governance is of great importance for them. Third, the evidence suggests that firms in Poland operate under severe credit rationing, while financing needs in a transition economy are high (Weller 2001). However, it is likely that public companies have better access to bank loans than other business entities as they are in better standing. However, firms in Poland (Tamowicz and Dzierzanowski 2002) like companies in some developed countries with very concentrated ownership (Pagano et al. 1998) as well as and in most of emerging economies (Wang et al. 2002; Mayur and Kumar 2006) go public for other reasons than to raise capital for investment.

At the beginning of the sample selection process 182 non-financial companies were distinguished. At the end of the year 1999 there were 221 companies listed on the Warsaw Stock Exchange. I exclude from this group 15 National Investment Funds and 24 financial enterprises. Over time, 34 firms dropped from the sample for 
the following reasons: financial distress and ultimately bankruptcy (13), transactions that took firms private as the results of strategic investor's decision (17) and mergers (4). Additional 6 firms were also excluded, because a complete set of the data regarding composition of the supervisory boards was unavailable. Over all I possess data on 568 firm-year. Since the sample contains firms with continuous data only, there might be a selectivity bias in the sample. However, in terms of results there should be no change in investment sensitivity to cash flow, because both good firms (those that were taken private) and bad firms (those that went bankrupt) were excluded from the sample.

Given the two-tier structure of board of directors in Poland, there are two ways, in which a firm might have a bank representative on the supervisory board. First, a bank's management team member can sit on firm's supervisory board. Second, when the same individual is a member of both a bank and firm's supervisory board. The first case was much more common in my sample. $86 \%$ of all bank's representatives on firm's supervisory boards were bank managers.

Placement of a banker on firm's supervisory board was common among listed companies. $49 \%$ of sample firms had at least one banker on the board during the years 1999-2002. Most of the time firms reported about one bank representative on the board (75\% of all observations). $21 \%$ of all observations concern situation, when a firm had two bankers on the board. Very rarely firms informed about three bank representatives (4\% of all observations).

The largest banks in Poland, that were privatized after restructuring process at the mid 90s., were the most active in developing relationship with their corporate clients by having their representatives on firm's board. $67 \%$ of bankers on the board were employees or were serving as supervisory board members of one of the six largest banks in Poland during 1999-2002. Those banks were also the largest creditors of the listed companies. Long-term loans granted to the sample firms by the six largest banks added up to $64 \%$ of all long-term credit delivered to all sample firms.

Having a bank representative on the board did not always indicate that firm was financed with credit. Sometimes banks placed their delegates on firm's supervisory boards in spite of that they were neither its creditors nor its shareholders. $39 \%$ of sample firms had at least one representative of bank-creditor on the board at least once during the years 1999-2002.

Table 1 shows some relevant statistics for the two sets of firms: with and without bankers on the board (for more detailed summary statistics see appendix Table 6). The subscript BT refers to firms that had a bank representative on their boards at least once during 1999-2002. The subscript NBT stands for firms that did not have at all bankers on the board during 1999-2002. The two types of firms differ significantly taking into account the following variables: cash flow, long-term and short-term bank loans, long-term other liabilities and size of firms (measured by natural $\log$ from the total assets).

Similar results were obtained by comparing two different sets of firms: with and without a bank-creditor representative on the board. The subscript BCT refers to firms that had a bank-creditor representative on the boards at least once during 1999-2002, and the subscript NBCT stands for firms, where there were no bankers from lending bank on the board during 1999-2002. 
Table 1 Summary statistics - comparing firms with bankers on the board (BT) and firms without bankers on the board (NBT) as well as firms with bank-creditor representative on the board (BCT) and firms, where bankers from lending banks are not sitting on the board (BNCT)

\begin{tabular}{|c|c|c|c|c|c|c|}
\hline & BT & NBT & Difference & BCT & BCT & Difference \\
\hline Mean I/K & 0.216 & 0.226 & 0.165 & 0.260 & 0.198 & 0.948 \\
\hline Median I/K & 0.077 & 0.098 & 0.857 & 0.079 & 0.088 & 0.093 \\
\hline Mean CF/K & 0.148 & 0.250 & $3.159 * * *$ & 0.144 & 0.234 & $2.684 * * *$ \\
\hline Median $\mathrm{CF} / \mathrm{K}$ & 0.133 & 0.184 & $3.513 * * *$ & 0.124 & 0.175 & $3.477 * * *$ \\
\hline Mean Q & 1.130 & 1.104 & 0.380 & 1.161 & 1.090 & 1.009 \\
\hline Median Q & 0.970 & 0.931 & $1.687^{*}$ & 0.979 & 0.922 & $2.596 * * *$ \\
\hline Mean S/K & 5.282 & 5.172 & 0.098 & 6.001 & 4.764 & 1.067 \\
\hline Median S/K & 2.876 & 2.930 & 1.604 & 3.190 & 2.852 & 0.152 \\
\hline Mean KD/K & 0.116 & 0.095 & 1.326 & 0.138 & 0.086 & $3.146 * * *$ \\
\hline Median KD/K & 0.040 & 0.000 & $2.869 * * *$ & 0.050 & 0.000 & $3.969 * * *$ \\
\hline Mean KK/K & 0.353 & 0.274 & $1.853 * *$ & 0.407 & 0.257 & $3.426 * * *$ \\
\hline Median KK/K & 0.217 & 0.173 & $2.705^{* * * *}$ & 0.258 & 0.162 & $4.38 * * *$ \\
\hline Mean IZD/K & 0.098 & 0.064 & $2.134 * *$ & 0.112 & 0.061 & $3.145^{* * *}$ \\
\hline Median IZD/K & 0.018 & 0.006 & 1.458 & 0.022 & 0.006 & $2.696 * * *$ \\
\hline Mean IZK/K & 1.242 & 1.189 & 0.183 & 1.430 & 1.086 & 1.144 \\
\hline Median IZK/K & 0.596 & 0.579 & 0.161 & 0.667 & 0.564 & $1.714 *$ \\
\hline Mean in size of total assets & 12.205 & 11.850 & $3.123 * * *$ & 12.319 & 11.846 & $4.05 * * *$ \\
\hline Median in size of total assets & 11.903 & 11.791 & $2.023 * *$ & 11.960 & 11.832 & $2.75 * * *$ \\
\hline
\end{tabular}

* Coefficient significant at $10 \%$ or better

** Coefficient significant at $5 \%$ or better

*** Coefficient significant at $1 \%$ or better

The statistics may support the hypothesis that firms appreciate bank relationship the most being in financial distress. The largest amount of bank loans went to firms that had a banker on the board and informed about negative cash flow from operating activities. This is a symptom of different state of financial distress such as: temporary financial distress, severe financial distress or insolvency. Firms may suffer from negative cash flow at the early stage of growth. This variant is not applicable to my sample, as it comprises of listed companies that are considered to be established firms. In my sample most of the firms were in temporal financial distress since they report negative cash flow just once or twice during the years 1999-2002. Only 3 out of 77 firms informed about financial distress for three years in a row (see appendix Table 7 for summary statistics).

\section{Regression results}

Table 2 reports regression results separately for the two sets of firms: with (BT) and without a banker on the board (NBT). The first and third columns show the results of the simple investment regression equation. Investment of firms with a banker on 
Table 2 Fixed effects regression relating investment to cash flow for firms with a banker on the board (BT) and for firms without bankers on the board (NBT) as well as for firms with a bank-creditor representative on the board (BCT) and for firms without bankers from lending bank on the board (NBCT)

\begin{tabular}{|c|c|c|c|c|c|c|}
\hline & \multicolumn{2}{|l|}{ BT } & \multicolumn{2}{|l|}{ NBT } & \multirow{2}{*}{$\begin{array}{l}\text { BCT } \\
5\end{array}$} & \multirow{2}{*}{$\begin{array}{l}\text { NBCT } \\
6\end{array}$} \\
\hline & 1 & 2 & 3 & 4 & & \\
\hline $\mathrm{CF} / \mathrm{K}_{\mathrm{t}-1}$ & $0.65 * *$ & $0.37 * *$ & $0.707 * * *$ & $0.533 * * *$ & $0.5^{* *}$ & $0.54 * * *$ \\
\hline Q & 0.01 & -0.01 & $0.413 * * *$ & $0.461 * * *$ & 0.00 & $0.45 * * *$ \\
\hline $\mathrm{S} / \mathrm{K}_{\mathrm{t}-1}$ & 0.006 & $(-0.07)^{* * *}$ & $0.033 * * *$ & -0.01 & -0.07 & -0.01 \\
\hline $\mathrm{CF} / \mathrm{K}_{\mathrm{t}-1} * \mathrm{Neg}$ & $(-1.47)^{* *}$ & -0.15 & $(-1.8)^{* * *}$ & $(-1.2)^{* * *}$ & -0.30 & $(-1.185)^{* * *}$ \\
\hline $\mathrm{LBL} / \mathrm{K}_{\mathrm{t}-1}$ & & $1.42 * * *$ & & $0.885 * * *$ & $1.4 * * *$ & $0.921 * * *$ \\
\hline $\mathrm{SBL} / \mathrm{K}_{\mathrm{t}-1}$ & & $1.47 * * *$ & & $0.302 * * *$ & $1.518 * * *$ & $0.314 * * *$ \\
\hline $\mathrm{OLL} / \mathrm{K}_{\mathrm{t}-1}$ & & $0.51 * * *$ & & -0.05 & $0.47 * *$ & 0.15 \\
\hline $\mathrm{OSL} / \mathrm{K}_{\mathrm{t}-1}$ & & $0.18 * * *$ & & $0.1609 * * *$ & $0.152 * *$ & $0.163 * * *$ \\
\hline $\mathrm{BH}$ & & 0.02 & & $0.182^{*}$ & 0.06 & 0.17 \\
\hline CO_1 & & -0.04 & & 0.16 & -0.03 & 0.16 \\
\hline CO_2 & & $(-0.61)^{* *}$ & & 0.47 & $(-0.691)^{* * *}$ & 0.39 \\
\hline CO_3 & & -0.07 & & 0.28 & -0.13 & 0.22 \\
\hline $\mathrm{CO}_{-} 4$ & & -0.13 & & 0.27 & -0.08 & 0.20 \\
\hline CO_5 & & NA & & 0.49 & NA & 0.35 \\
\hline $\mathrm{T} 2$ & $(-0.358)^{* * *}$ & $(-0.28)^{* * *}$ & 0.08 & 0.03 & $(-0.3)^{* * *}$ & -0.02 \\
\hline $\mathrm{T} 3$ & $(-0.45)^{* * *}$ & $(-0.49)^{* * *}$ & -0.01 & -0.05 & $(-0.507) * * *$ & $(-0.117)^{*}$ \\
\hline $\mathrm{T} 4$ & $(-0.477)^{* * *}$ & $(-0.44) * * *$ & -0.29 & -0.01 & $(-0.487)^{* * *}$ & -0.07 \\
\hline Constant & $0.344 * * *$ & 0.00 & $(-0.658) * * *$ & $(-1.06)^{* * *}$ & -0.08 & $(-0.954)^{* * *}$ \\
\hline$p$ value $(\mathrm{F})$ & 0.4 & 0.00 & 0.00 & 0.00 & 0.00 & 0.00 \\
\hline Hausman test & 0.9 & 0.13 & 0.00 & 0.00 & 0.00 & 0.00 \\
\hline R2 within & 0.14 & 0.64 & 0.63 & 0.71 & 0.70 & 0.65 \\
\hline $\mathrm{R} 2$ between & 0.11 & 0.14 & 0.41 & 0.39 & 0.10 & 0.35 \\
\hline R2: overall & 0.13 & 0.39 & 0.52 & 0.54 & 0.42 & 0.48 \\
\hline $\mathrm{N}$ & 276 & 276 & 292 & 292 & 212 & 356 \\
\hline
\end{tabular}

The dependent variable, fixed capital investment I, is regressed on cash flow- $\mathrm{CF}$, market-to-book ratio$\mathrm{Q}$, income from sales, negative cash flow- $\mathrm{CF}^{*} \mathrm{Neg}$ (where Neg is a dummy variable equals 1 , when cash flow is negative, 0 otherwise), long-term-LBL and short-term-SBL bank loans, other long-term-OLL and short-term liabilities_-OSL, a dummy for bank equity holdings-BH, ownership concentration dummies from 1 to 5-OC, annual variable indicators $(\mathrm{t} 2, \mathrm{t} 3, \mathrm{t} 4)$. Level variables are normalized by fixed capital at the beginning of the year- $\mathrm{K}(\mathrm{t}-1)$

* Coefficient significant at $10 \%$ or better

** Coefficient significant at $5 \%$ or better

*** Coefficient significant at $1 \%$ or better

the board was less sensitive to cash flow than investment of firms without bank representatives on the board. The second and fourth columns present results from an extended regression equation. The difference in investment-cash flow sensitivity between the two sets of firms increased significantly. Again, internal capital was less important source of financing for firms with a banker on the board than for firms 
without bank board representation, because the former were less financially constrained than the latter.

The two set of firms differ significantly as far as the level of bank financing, both long-term and short-term, is concerned. The estimated coefficient of the variable indicating long-term bank loans was twice as large for firms with a banker on the board than for firms without bank representatives on the board. In case of short-term bank loans estimated coefficient was five times larger for firms with a banker on the board than for firms without bankers on the board. It suggests that bank financing was far more important for firms with a banker on the board than for firms without bank board representation.

In addition, the results reveal that for firms with a banker on the board the coefficients of both long-term and short-term bank loans were nearly five times larger than coefficient of cash flow. For those firms bank loans were more important for investment financing than internal capital. In contrast, for firms with no bank representatives on the board estimated coefficient of cash flow was twice as large as estimated coefficient of short-term bank loans. Thus, for this set of firms internal capital was more significant than short-term bank loans for investment financing. Estimated coefficient of long-term bank loans was larger than estimated coefficient of cash flow. Given that more than $50 \%$ of the firms did not receive long-term bank loans those results support the hypothesis that they were more financially constrained (see Table 2). Consistent with previous studies, it appears that bankers are on the board to supply debt market expertise. Booth and Deli (1999) present the findings that the presence of bankers on the board is positively related to both short and long-term bank debt. Dittmann et al. (2009) confirm that bankers while sitting on firm's board provide capital market expertise and thus help these firms to overcome financial constraints.

The relation between investment spending and the level of investment opportunities - measured by the market-to-book ratio-was positive and statically significant just for firms without bank representatives on the board. They were smaller - as the summary statistics show-than firms with bankers on the board and therefore were likely to have bigger incentives to invest and grow.

For both sets of firms the estimated coefficient indicating other short-term liabilities was statistically significant, but its impact on investment spending was much smaller than bank loans. As far as other long-term liabilities are concerned their increase was related to a rise in investment expenditures, but just for firms with a banker on the board. Other creditors may treat bank board representation as a mechanism that can assure themselves debt repayments. It is consistent with the results that bankers on the boards provide certification for other creditors (Byrd and Mizruchi 2005).

Production that may lead to increase capacity appeared to influence investment spending of firms with a banker on the board. However, it had very minor impact as the estimated coefficient of income from sales was negative, but very close to zero.

Ownership concentration was not statistically significant variable except from firms with a banker on the board and with $75 \%$ shares concentrated in hands of two or three shareholders. In that case investment expenditures were negatively related 
to ownership concentration. It may indicate that the largest investors undertook a firm restructuring. However, assets stripping hypothesis cannot be rejected.

A variable that indicates bank equity holding was included to the investment equation, because the role of bank as shareholder may be important for firm investment decisions. The effect of this variable was insignificant for firms that had a bank representative on the board. On the other hand, for firms without bankers on the board bank equity holding was positively and significantly related to investment expenditures.

Last, but not least, investment expenditures were very much sensitive to macro environment. From the data we see that the economic downturn from 2000 to 2002 had a negative impact on investment activities. Firms with a banker on the boards reacted quickly on a decline of economic growth by decreasing of the amount spent on investment. Macro situation had no impact on investment of firms without bankers on the board. It shows that bankers may play important certification role on firm's board.

To investigate whether placement of a banker on the board indicates bank monitoring I repeated estimation, classifying firms into two sub-sample differently. First group (BCT) consisted of firms with a lender representative on the board at least once during the research period 1999-2002. Second group (NBCT) included firms without presence of bank-creditor on the board.

Table 2 (fifth and sixth columns) demonstrates that investment of firms with bank-creditor representatives on the board was almost as sensitive to cash flow as investment of firms without the presence of bank-creditor on the board. The difference in investment-cash flow sensitivity between two distinguished subsamples appeared to be very small. Firms with affiliated bankers on the board faced similar financial constraints in their investment decisions as firms with unaffiliated bankers on the board.

Consistent with previous research I do not find evidence that bankers on the boards of other firms are not primarily as monitors. Booth and Deli (1999) finds that the presence of bankers on the board is positively related to short-term, long, term and total bank debt, however the presence of bankers that have business relationship with the firm is not linked to the bank borrowing. Thus, the results suggest that bankers on the board supply financial expertise to firms, they do not sit on boards to monitor debtors. Dittmann et al. (2009) suggest that bankers do not join the board to monitor debtors and they do not tend to change their behaviour. Byrd and Mizruchi (2005) complement those findings by showing that the presence of bank-lenders on the board may not be solely explained by information asymmetries, but may be a compound function of information asymmetries and the threat of firm's financial distress.

\section{Controlling for possible selection bias}

To control for selectivity bias that can arise at the firm level, I use the fixed effects estimation that takes care of the selection bias related to non-random exit from the sample. However, selectivity bias might not be related to firm's identity 
characteristics. It may occur in the choice of a measure of bank monitoring, and then explains the difference in the investment-cash-flow sensitivity between firms with a banker on the boards and firms without bank board representation. To cope with the problem I use, like in previous papers, the method described by Dubin and McFadden (1984). It involves first estimating logit model on the choice of a banker on the board, and then using the predicted probability from the logit model as an exogenous variable in the investment equation.

Table 3 (1st column) presents the outcome of logit regressions. The relation between a dummy variable representing the presence of a banker on the board and the following independent variables: cash flow, firm's size, dummy for bank equity holdings, ownership concentration and short-term bank loans as well as other longterm liabilities is significant.

Negative estimated coefficient of cash flow indicates that the lower level of cash flow, the higher the probability of having a banker on the board. In other words, in Poland bank representatives sit on the board of those firms that are likely to be in financial distress. Hoshi et al. (1990) conclude that based on example of Japan the costs of financial distress are lower for firms with close bank relationship. In contrast, in the US bankers are less likely to be on the board of firms that could

Table 3 Logit estimates: firm characteristics associated with having a banker on the board (1st column) and firm characteristics associated with having a bank-creditor representative on the board (2nd column)

\begin{tabular}{lll}
\hline & 1 & 2 \\
\hline $\mathrm{I} / \mathrm{K}_{\mathrm{t}-1}$ & 0.024 & 0.0930 \\
$\mathrm{LBL} / \mathrm{K}_{\mathrm{t}-1}$ & 0.166 & 0.7700 \\
$\mathrm{SBL} / \mathrm{K}_{\mathrm{t}-1}$ & $0.445127^{*}$ & $0.568^{* *}$ \\
$\mathrm{LEV}$ & 0.290 & 0.7440 \\
$\mathrm{OLL} / \mathrm{K}_{\mathrm{t}-1}$ & $0.885715^{*}$ & $1.457 * * *$ \\
OSL/K $\mathrm{t}-1$ & -0.054 & -0.0380 \\
$\mathrm{~S} / \mathrm{K}_{\mathrm{t}-1}$ & 0.009 & 0.0083 \\
$\mathrm{CF} / \mathrm{K}_{\mathrm{t}-1}$ & $(-0.993011)^{* * *}$ & $(-1.01)^{* * *}$ \\
$\mathrm{Q}$ & -0.013 & 0.0100 \\
$\mathrm{In} \mathrm{size} \mathrm{of} \mathrm{total} \mathrm{assets}$ & $(-0.079497)^{* * *}$ & $(-0.134)^{* * *}$ \\
$\mathrm{CO}$ & $0.135984^{* *}$ & 0.0700 \\
$\mathrm{BH}$ & $1.158681^{* * *}$ & $1.12^{* * * *}$ \\
$\mathrm{R} 2$ & 0.485 & 0.45 \\
$\mathrm{~N}$ & 568 & 568
\end{tabular}

The dependent variable takes the value 1, when firms have bank representatives on firm supervisory board, otherwise 0 . The independent variables encompass: fixed capital investment I, cash flow-CF, market-to-book ratio- Q, income from sales, long-term-LBL and short-term-SBL bank loans, other long-term-OLL and short-term liabilities-OSL, a dummy for bank equity holdings-BH, ownership concentration dummies from 1 to 5 - OC. All the level variables are normalized by fixed capital at the beginning of the year- $\mathrm{K}(\mathrm{t}-1)$. Lev is relation between the bank loans and all liabilities

* Coefficient significant at $10 \%$ or better

** Coefficient significant at $5 \%$ or better

*** Coefficient significant at $1 \%$ or better 
benefit most from active bank monitoring and they do not join a firm's board during distress consistent with an important role for lender liability and potential conflicts. The role of bankers on the board is very much dependent on the regulatory regime (Kroszner and Strahan 2001).

Also, the value of estimated coefficient of size of firm is negative. It means that probability of a banker's appointment to the board increases with the size of firm. Additionally, the presence of a banker is determined by the possibility of voting itself into board, as direct bank shareholding is highly significant. Besides, the more concentrated ownership, the higher probability of having bank board representation. It implies the conflict of interests between a large shareholder and a creditor. Banks may be afraid that large shareholder can undertake more risky project as it was agreed upon in the credit contract. The higher risk, the higher return on investment for shareholders. Creditors receive fixed return on their investment.

Short-term bank loans and long-term other liabilities predict positively for a firm to have a banker on the board. One interpretation is that bankers sit on the supervisory board of those firms that finance their activities with short-term credit. Also, banks tend to have their representatives on the board to oversee whether other creditors do not intend to satisfy their claims at their cost.

In contrast, investment expenditures, level of production and future profitability of firm's investment do not offer positive predictions of bank board representation. It means that banks do not sit on the board of those firms that grow faster or have better investment perspectives.

At the second stage of Dubina and McFaddena's test I examine whether the characteristics, that predict bank's board representation, are related to investment expenditures. I estimate the investment equation for two sets of firms using random effects model that includes predicted probabilities of the presence of a banker on the board as an exogenous variable. The coefficient of the additional variable measures the correlation between unobserved firm effects and unobserved factors that affect likelihood of having a banker on the board. Hence, it indicates the significance and size of selectivity bias.

The outcome of random effect regression for firms with a banker on the board (see Table 4, column 1) shows that effect of selectivity bias on investment-cash flow sensitivity is limited. The coefficient on the selectivity term is not statistically significant. As far as firms without bank's board representation are concerned, the additional variable (the predicted probability from the logit model) has significant influence on the investment expenditures. After including this variable investmentcash flow sensitivity has increased. Hence, selectivity bias causes underestimation of investment-cash flow sensitivity for firms without bankers on the board.

I also use the Dubin and McFadden test to control for selectivity bias when bank monitoring is measured by the close relationship with lending bank through board representation. Results of logit regression (Table 4) demonstrate that relation between the presence of bank-creditor on the board and the following independent variables: cash flow, firm's size, dummy for bank equity holdings, short-term bank loans as well as other long-term liabilities is significant. Note that the same variables decide about the presence of a banker on the board. 
Table 4 Random effects estimates of the investment equation for firms with a banker on the board (BT) and for firms without bankers on the board (NBT) as well as for firms with a bank-creditor representative on the board (BCT) and for firms without bankers from lending bank on the board (NBCT)

\begin{tabular}{|c|c|c|c|c|}
\hline & $\begin{array}{l}\text { BT } \\
1\end{array}$ & $\begin{array}{l}\text { NBT } \\
2\end{array}$ & $\begin{array}{l}\mathrm{BCT} \\
3\end{array}$ & $\begin{array}{l}\text { NBCT } \\
4\end{array}$ \\
\hline $\mathrm{CF} / \mathrm{K}_{\mathrm{t}-1}$ & 0.10 & $1.6 * * *$ & $0.53^{*}$ & $0.75 * * *$ \\
\hline Q & -0.04 & $0.286^{* * * *}$ & -0.02 & $0.314 * * *$ \\
\hline $\mathrm{S} / \mathrm{K}_{\mathrm{t}-1}$ & $(-0.049) * * *$ & $(-0.03)^{* * *}$ & $(-0.049)^{* * *}$ & -0.01 \\
\hline $\mathrm{CF} / \mathrm{K}_{\mathrm{t}-1} * \mathrm{Neg}$ & -0.15 & -0.55 & -0.25 & -1.11 \\
\hline $\mathrm{LBL} / \mathrm{K}_{\mathrm{t}-1}$ & $0.87 * * *$ & $0.3 *$ & $0.86^{* * *}$ & $0.49 * * *$ \\
\hline $\mathrm{SBL} / \mathrm{K}_{\mathrm{t}-1}$ & $1.304 * * *$ & $(-0.378) * * *$ & $1.22 * * *$ & 0.11 \\
\hline $\mathrm{OLL} / \mathrm{K}_{\mathrm{t}-1}$ & $0.585 * *$ & $(-0.93)^{* * *}$ & 0.39 & -0.13 \\
\hline $\mathrm{OSL} / \mathrm{K}_{\mathrm{t}-1}$ & $0.105^{*}$ & $0.222^{* * *} *$ & $0.117^{*}$ & $0.122^{* * * *}$ \\
\hline $\mathrm{BH}$ & 0.38 & $(-1.41)^{* * * *}$ & -0.02 & -0.14 \\
\hline CO_1 & -0.06 & -0.13 & -0.10 & -0.05 \\
\hline CO_2 & $(-0.476)^{* *}$ & -0.22 & $(-0.62)^{* *}$ & 0.07 \\
\hline CO_3 & -0.10 & $(-0.55)^{* * *}$ & $(-0.33)^{*}$ & 0.00 \\
\hline CO_4 & -0.06 & $(-0.66)^{* * *}$ & -0.27 & -0.04 \\
\hline CO_5 & NA & -0.76 & NA & 0.07 \\
\hline $\mathrm{T} 2$ & $(-0.291)^{* * *}$ & 0.00 & $(-0.313)^{* * *}$ & -0.02 \\
\hline $\mathrm{T} 3$ & $(-0.484)^{* * *}$ & -0.09 & $(-0.5)^{* * *}$ & -0.15 \\
\hline $\mathrm{T} 4$ & $(-0.47) * * *$ & -0.10 & $(-0.53) * * *$ & $(-0.12)^{*}$ \\
\hline $\begin{array}{l}\text { The predicted probability } \\
\text { from the logit model }\end{array}$ & 1.66 & $(-5.7)^{* * *}$ & 0.11 & $(-0.588)^{*}$ \\
\hline Constant & -0.77 & $(-2.3)^{* * *}$ & 0.25 & $(-0.59)^{* * *}$ \\
\hline$p$ value $(\mathrm{F})$ & 0.00 & 0.00 & 0 & 0.00 \\
\hline R2 within & 0.60 & 0.73 & 0.67 & 0.64 \\
\hline R2 between & 0.21 & 0.50 & 17 & 0.40 \\
\hline R2: overall & 0.43 & 0.64 & 0.46 & 0.52 \\
\hline $\mathrm{N}$ & 276 & 292 & 212 & 356 \\
\hline
\end{tabular}

The dependent variable, fixed capital investment $\mathrm{I}$, is regressed on cash flow-CF, market-to-book ratio$\mathrm{Q}$, income from sales, negative cash flow- $\mathrm{CF}^{*} \mathrm{Neg}$ (where Neg is a dummy variable equals 1 , when cash flow is negative, 0 otherwise), long-term-LBL and short-term-SBL bank loans, other long-term-OLL and short-term liabilities-OSL, a dummy for bank equity holdings- $\mathrm{BH}$, ownership concentration dummies from 1 to $5-\mathrm{OC}$, annual variable indicators $(\mathrm{t} 2, \mathrm{t} 3, \mathrm{t} 4)$. Level variables are normalized by fixed capital at the beginning of the year- $\mathrm{K}(\mathrm{t}-1)$

* Coefficient significant at $10 \%$ or better

** Coefficient significant at $5 \%$ or better

*** Coefficient significant at $1 \%$ or better

Results of random effects regression for firms with a banker from lending bank on the board (Table 4, column 2) show that relation between additional variable and investment expenditures is not statistically significant. Hence, selectivity bias does not influence investment-cash flow sensitivity. However, for firms without bank- 
creditor's representatives on the boards investment spending is positively and significantly related to the predicted probability of additional variable from logit regression. After including the additional variable to equation investment-cash flow sensitivity increased. Thus, selectivity bias causes underestimation of investmentcash flow sensitivity for firms without bank-creditor board representation. Based on the results from Dubin and McFadden's test bankers on the board is an adequate measure of bank monitoring.

\section{Conclusions}

On the threshold of the transition process from a centrally planned to a market economy in the Central and Eastern Europe banks were to play a dominant role in corporate governance given the underdeveloped equity market and the existing, under a socialist regime, close relationship between lenders and state enterprises. However, due to overwhelming problems with bad debts and on-going bank's privatization in 90s, there were hardly any evidence that banks got involved in active debtor's monitoring through firm's board representation.

After more than a decade of transition reforms the research outcome shows that bank credits have an important role in firm's financing. Firms with a bank-creditor representative on the board rely more heavily on bank loans than on internal capital while making investment decisions. In contrast, firms without a bank-creditor representative on the board finance to a larger extent their investment with internal capital than bank loans. Bank loans are also more important source of financing for firms with a banker on the board than for firms without the bank board representation.

However, the empirical results also demonstrate that firms with a bank-creditor representative on the board are as much financially constrained in their investment behaviour than firms without the presence of a bank-creditor on the board. Thus, the study yields the conclusion that bankers on the boards of Polish firms do not perform monitoring function as lenders. They rather use their placement in order to promote bank's business by granting more credits to firms, where they sit on the supervisory board. The findings show that investment of firms with a banker on the board is less sensitive to cash flow than investment of firms without bank representatives on the board. The result suggests that bankers on the board provide financial expertise that help those firm to reduce financial constraints.

Open Access This article is distributed under the terms of the Creative Commons Attribution License which permits any use, distribution, and reproduction in any medium, provided the original author(s) and the source are credited.

\section{Appendix}

See Tables 5, 6 and 7 
Table 5 Definition and description of all variables used in the paper

\begin{tabular}{|c|c|c|}
\hline Variable & Definition of variable & Description \\
\hline Iit & $\begin{array}{l}\text { Investment spending in fix } \\
\text { assets of the ith firm in t } \\
\text { time }\end{array}$ & $\begin{array}{l}\text { Investment is an explained variable and is } \\
\text { calculated as the first difference of gross } \\
\text { fixed assets expenditures. Fixed assets } \\
\text { include land, property, plant, equipment } \\
\text { and patents }\end{array}$ \\
\hline Qit & $\begin{array}{l}\text { Tobin } Q \text { of the ith firm in } t \\
\text { time }\end{array}$ & $\begin{array}{l}\text { Tobin } Q \text { is an explanatory variable } \\
\text { represents future growth investment } \\
\text { opportunities, which is proxied by market- } \\
\text { to-book ratio }\end{array}$ \\
\hline CFit & $\begin{array}{l}\text { Cash flow of the ith firm in } t \\
\text { time }\end{array}$ & $\begin{array}{l}\text { Cash flow is an explanatory variable } \\
\text { measured as net income plus non-cash } \\
\text { costs (e.g. depreciation) minus non cash } \\
\text { expenditure }\end{array}$ \\
\hline $\mathrm{CF}^{*}$ Negit & $\begin{array}{l}\text { Negative cash flow of the ith } \\
\text { firm in t time }\end{array}$ & $\begin{array}{l}\text { Neg is a dummy variable equals } 1 \text {, when } \\
\text { cash flow is negative, } 0 \text { otherwise }\end{array}$ \\
\hline$K i(t-1)$ & $\begin{array}{l}\text { Stock of fixed assets at the } \\
\text { beginning of the period } t\end{array}$ & $\begin{array}{l}\text { To avoid heteroskedasticity all variables in } \\
\text { the model are normalized by the stock of } \\
\text { fixed assets at the beginning of the period } t\end{array}$ \\
\hline Sit & $\begin{array}{l}\text { Revenue from sales of the ith } \\
\text { firm in } t \text { time }\end{array}$ & $\begin{array}{l}\text { Revenue from sales as the proxy for } \\
\text { production to control for a potential } \\
\text { accelerator effect. High level of production } \\
\text { may lead to increase capacity in the future, } \\
\text { hence more fix assets investment } \\
\text { expenditures are necessary }\end{array}$ \\
\hline LBLit & $\begin{array}{l}\text { Long-term bank loans of the } \\
\text { ith firm in t time }\end{array}$ & $\begin{array}{l}\text { The volume of long-term bank credits on } \\
\text { firm's books }\end{array}$ \\
\hline SBLit & $\begin{array}{l}\text { Short-term bank loans of the } \\
\text { ith firm in t time }\end{array}$ & $\begin{array}{l}\text { The volume of short-term bank credits on } \\
\text { firm's books }\end{array}$ \\
\hline OLLit & $\begin{array}{l}\text { Other long-term liabilities of } \\
\text { the ith firm in t time }\end{array}$ & $\begin{array}{l}\text { The volume of other long-term liabilities on } \\
\text { firm's books }\end{array}$ \\
\hline OSLit & $\begin{array}{l}\text { Other short-term liabilities of } \\
\text { the ith firm in t time }\end{array}$ & $\begin{array}{l}\text { The volume of other short-term bank credits } \\
\text { on firm's books }\end{array}$ \\
\hline BHit & $\begin{array}{l}\text { Bank's equity holding of the } \\
\text { ith firm in t time }\end{array}$ & $\begin{array}{l}\text { A dummy variable that equals } 1 \text {, if there is at } \\
\text { least one bank among firm's shareholders, } \\
0 \text { otherwise }\end{array}$ \\
\hline OCit & $\begin{array}{l}\text { Concentration of firm } \\
\text { ownership structure of the } \\
\text { ith firm in t time }\end{array}$ & $\begin{array}{l}\text { The variable takes values from } 1 \text {-the most } \\
\text { concentrated firm ownership structure to } \\
\text { do 5-the lowest level of concentration. } \\
\text { When the variable OC is set as } 1 \text { then it } \\
\text { means that single shareholder holds more } \\
\text { than } 75 \% \text {. If two or three shareholders } \\
\text { hold more than } 75 \% \text { than the variable is } \\
\text { equal } 2 \text {. Concentration is set as } 3 \text { when the } \\
\text { single shareholder holds more } 50 \% \text { and } \\
\text { relatively } 4 \text { if two or three shareholders } \\
\text { hold more than } 50 \% \text {. Concentration is } \\
\text { considered to be } 5 \text { in all the cases in which } \\
\text { the concentration is more dispersed than } \\
50 \%\end{array}$ \\
\hline $\mathrm{T} 1,2,3$ & Years of analysis & Yearly dummies \\
\hline
\end{tabular}




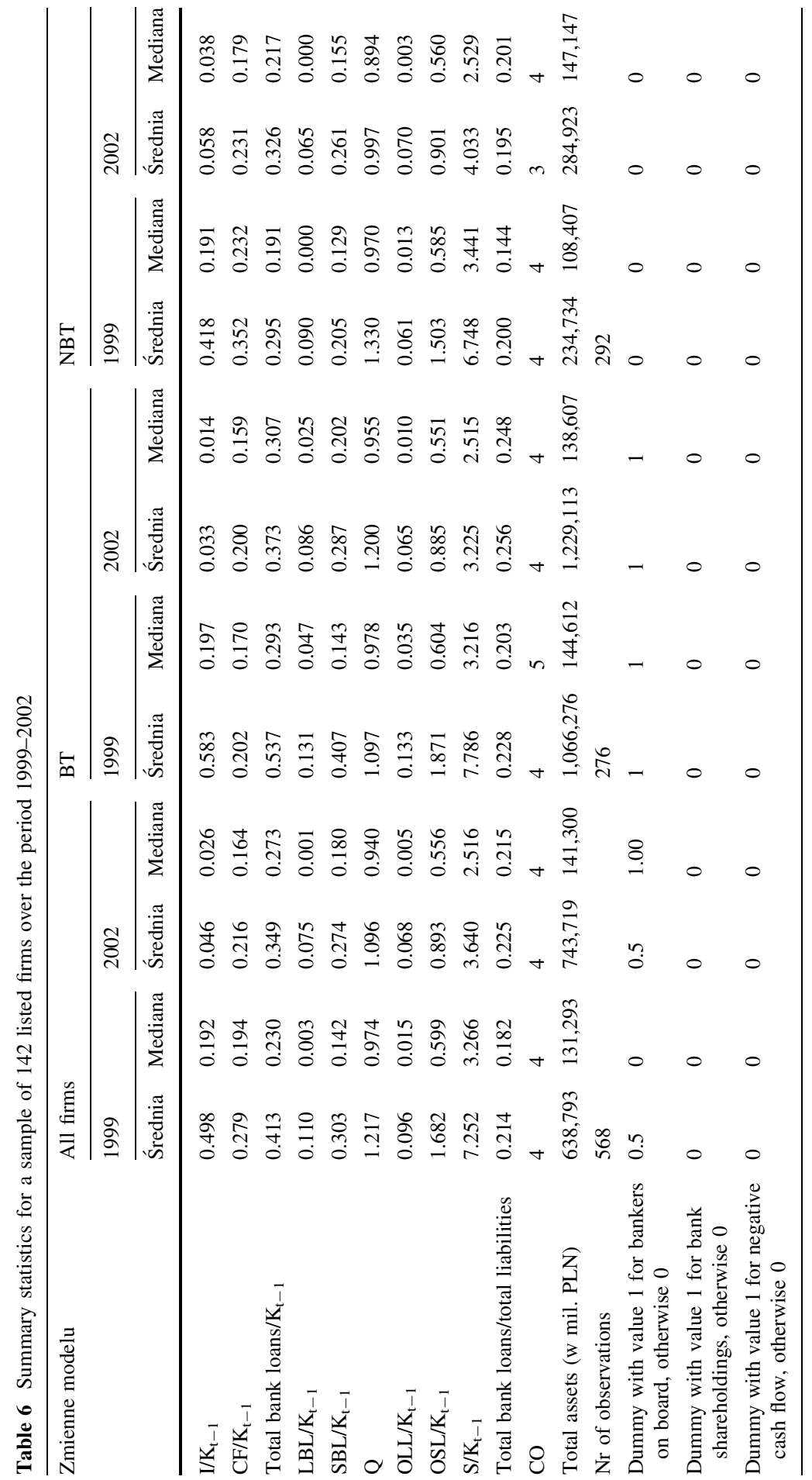


Table 7 Descriptive statistics for sample of firms that reported about negative cash flow at least once during 1999-2002 spitted for firms with a banker on the board (BT) and for firms without bankers on the board

\begin{tabular}{|c|c|c|c|c|c|c|c|c|}
\hline & \multicolumn{4}{|l|}{ BT } & \multicolumn{4}{|l|}{ NBT } \\
\hline & \multicolumn{2}{|l|}{1999} & \multicolumn{2}{|l|}{2002} & \multicolumn{2}{|l|}{1999} & \multicolumn{2}{|l|}{2002} \\
\hline & Mean & Median & Mean & Median & Mean & Median & Średnia & Mediana \\
\hline $\mathrm{I} / \mathrm{K}_{\mathrm{t}-1}$ & 0.591 & 0.246 & -0.006 & -0.012 & 0.545 & 0.286 & 0.070 & 0.024 \\
\hline $\mathrm{CF} / \mathrm{K}_{\mathrm{t}-1}$ & 0.146 & 0.091 & 0.185 & 0.130 & 0.414 & 0.265 & 0.194 & 0.127 \\
\hline $\begin{array}{l}\text { Total bank loans/ } \\
\mathrm{K}_{\mathrm{t}-1}\end{array}$ & 0.667 & 0.389 & 0.471 & 0.427 & 0.314 & 0.177 & 0.407 & 0.309 \\
\hline $\mathrm{LBL} / \mathrm{K}_{\mathrm{t}-1}$ & 0.164 & 0.064 & 0.090 & 0.014 & 0.073 & 0.000 & 0.079 & 0.000 \\
\hline $\mathrm{SBL} / \mathrm{K}_{\mathrm{t}-1}$ & 0.503 & 0.254 & 0.381 & 0.328 & 0.242 & 0.129 & 0.327 & 0.209 \\
\hline Q & 1.071 & 0.984 & 1.329 & 0.977 & 1.638 & 1.007 & 1.007 & 0.899 \\
\hline $\mathrm{OLL} / \mathrm{K}_{\mathrm{t}-1}$ & 0.143 & 0.050 & 0.057 & 0.024 & 0.074 & 0.022 & 0.058 & 0.003 \\
\hline $\mathrm{OSL} / \mathrm{K}_{\mathrm{t}-1}$ & 2.704 & 0.849 & 1.138 & 0.821 & 2.356 & 0.986 & 1.264 & 0.918 \\
\hline $\mathrm{S} / \mathrm{K}_{\mathrm{t}-1}$ & 10.848 & 3.806 & 3.661 & 2.552 & 10.412 & 5.114 & 5.523 & 3.194 \\
\hline $\begin{array}{c}\text { Total bank loans/ } \\
\text { total liabilities }\end{array}$ & 0.242 & 0.204 & 0.273 & 0.250 & 0.163 & 0.068 & 0.189 & 0.200 \\
\hline $\mathrm{CO}$ & 4.35 & 5 & 3.9 & 4 & 3.59 & 4 & 3.30 & 4 \\
\hline $\begin{array}{l}\text { Total assets } \\
\text { (w mil. PLN) }\end{array}$ & 575,835 & 134,387 & 407,612 & 101,016 & 149,002 & 94,267 & 200,633 & 93,108 \\
\hline No of observations & 160 & & & & 148 & & & \\
\hline $\begin{array}{l}\text { Dummy with value } \\
1 \text { for bankers on } \\
\text { board, otherwise } \\
0\end{array}$ & 1 & 1 & 1 & 1 & 0 & 0 & 0 & 0 \\
\hline $\begin{array}{l}\text { Dummy with value } \\
1 \text { for bank } \\
\text { shareholdings, } \\
\text { otherwise } 0\end{array}$ & 0.48 & 0 & 0.55 & 1 & 0.14 & 0 & 0.19 & 0 \\
\hline $\begin{array}{l}\text { Dummy with value } \\
1 \text { for negative } \\
\text { cash flow, } \\
\text { otherwise } 0\end{array}$ & 0.38 & 0 & 0.15 & 0 & 0.27 & 0 & 0.27 & 0 \\
\hline
\end{tabular}

\section{References}

Abel, A., \& Blanchard, O. (1986). Investment and sales: Some empirical evidence. Working Paper 2050: National Bureau of Economic Research.

Akerlof, G. (1970). The market for "lemons": Quality uncertainty and the market mechanism. The Quarterly Journal of Economics, 84, 488-500.

Allayanis, G., \& Mozumdar, A. (2004). The impact of negative cash flow and influential observations on investment-cash flow sensitivity estimates. Journal of Banking \& Finance, 28, 901-930.

Bae, K., Kang, K., \& Lim, C. (2002). The value of durable bank relationships: Evidence from Korean banking shocks. Journal of Financial Economics, 64, 81-214.

Baer, H. L., \& Gray, C. W. (1996). Debt as a control device in transitional economies: The experiences of Hungary and Poland. In R. Frydman, Ch. Gray, \& A. Rapaczyński (Eds.), Corporate governance in central Europe and Russia. Budapest: Central European University Press. 
Booth, J. R., \& Deli, D. N. (1999). On executives of financial institutions as outside directors. Journal of Corporate Finance, 5, 227-250.

Byrd, D., \& Mizruchi, M. (2005). Bankers on the board and the debt ratio of firms. Journal of Corporate Finance, 11, 129-173.

Ciamarra, E. (2006). Monitoring by affiliated bankers on boards of directors: Evidence from corporate financing outcomes. Brandeis University.

Diamond, D. (1984). Liquidity intermediation and delegated monitoring. Review of Economic Studies, 51, 393-414.

Dittmann, I., Maug, E., \& Schneider, C. (2009). Bankers on the boards of German firms: What they do, what they are worth, and why they are (still) there. Review of Finance, forthcoming.

Dittus, P., \& Prowse, S. (1995). Corporate control in central Europe and Russia. World bank policy research: working paper 1481.

Dubin, J., \& McFadden, D. (1984). An econometric analysis of residential electric appliance holdings and consumption. Economtrica, 52, 345-362.

EBRD. (1999). Transition report 1998: Financial sector in transition.

Elsas, R., \& Krahnen, J. (1998). Is relationship lending special? Evidence from credit-file data in German. Journal of Banking \& Finance, 22, 1283-1316.

Elston, J. A. (1996). Investment, liquidity constraints, and the bank relationship: Evidence from German Manufacture firms. Conference Paper, Washington: The American Institute for Contemporary German Studies.

Fama, E. (1985). What's different about banks. Journal of Monetary Economics, 15, 29-39.

Fazzari, S. M., Hubbard, R. G., \& Petersen, B. C. (1988). Financing constraints and corporate investment. Brooking Papers on Economic Activity, 1, 141-195.

Ferri, G., Kang, T., \& Kim, I. (2001). The value of relationship banking during financial crises: Evidence from the republic of Korea. working paper no. 2553, World Bank.

Fohlin, C. (1998). Relationship banking, liquidity, and investment in the German industrialization. Journal of Finance, 53, 1737-1758.

Gilson, S. C. (1990). Bankruptcy, boards, banks, and blockholders: Evidence on changes in corporate ownership and control when firms default. Journal of Financial Economics, 27, 355-387.

Gomułka, S. (1993). The financial situation of polish enterprises (1992-1993) and its impact on monetary and fiscal policies. Research Paper Series No. EE-RPS28, Washington: World Bank.

Gray, C., \& Holle, A. (1996). Bank-led restructuring in Poland: An empirical look at the bank conciliation process. World Bank Policy Research Department: working paper no. 1650.

Harm, C. (1996). Investment, liquidity, and banking lending in Germany. Copenhagen Business School.

Hoshi, T., Kashyap, A., \& Scharfstein, D. (1990). The role of banks in reducing the costs of financial distress in Japan. Journal of Financial Economics, 27, 67-88.

Hoshi, T., Kashyap, A., \& Scharfstein, D. (1991). Corporate structure, liquidity and investment. Quarterly Journal of Economics, 106, 33-60.

Houston, J., \& James, Ch. (2001). Do relationships have limits? Banking relationships, liquidity constraints and investment. Journal of Business, 74, 347-374.

Kaplan, S., \& Minton, B. (1994). Appointments of outsiders to Japanese boards: Determinants and implications for managers. Journal of Financial Economics, 36, 225-258.

Kim, Y., Park, K., Ratti, R., \& Shin, H. (2002). Do main banks extract rents from their client firms? Tokio: CEI working paper series no. 2002-2009.

Konings, J., Rizov, M., \& Vandenbussche, H. (2002). Investment and credit constraints in transition economies: Micro evidence from Poland, the Czech Republic, Bulgaria and Romania. LICOS Discussion Paper: Discussion Paper 112.

Kracaw, W., Zenner, M. (1998). Bankers in the boardroom: Good news or bad news? Working Paper, Smeal College of Business Administration: Pennsylvania State University.

Kroszner, R., \& Strahan, P. (2001). Bankers on boards: Monitoring, conflicts of interest, and lender liability. Journal of Financial Economics, 62, 415-452.

Lorsch, J. W., \& MacIver, E. (1989). Pawns and potentates: The reality of america's corporate boards. Boston, MA: Harvard Business School Press.

Mace, M. L. (1971). Directors: Myth and reality. Boston, MA: Harvard Business School Press.

Mayur, M., Kumar, M. (2006). An empirical investigation of going public decision of Indian companies. Germany: MPRA Paper 1801, University Library of Munich.

McGuire, P. (2003). Bank ties and bond markets access: Evidence on investment-cash flow sensitivity in Japan. NBER. 
Modigliani, F., \& Miller, M. (1958). The cost of capital, corporation finance and the theory of investment. American Economic Review, 48, 261-297.

Morck, R., \& Nakamura, M. (1999). Banks and corporate control in Japan. Journal of Finance, 54(1), 319-339.

Myers, S., \& Majluf, N. (1984). Corporate financing and investment decisions when firms have information that investors do not have. Journal of Liquidity Economics, 13, 187-221.

Ongena, S., \& Smith, D. C. (2000). What determines the number of relationships? Cross country evidence. Journal of Financial Intermediation, 9, 26-56.

Pagano, M., Panetta, F., \& Zingales, L. (1998). Why do companies go public? An empirical analysis. Journal of Finance, 53(1), 27-64.

Pawłowicz, L. (1994, 1995). Restrukturyzacja finansowa przedsiębiorstw i banków I i II, IBnG, Gdańsk.

Rajan, R. (1992). Insiders and outsiders: The choice between informed and arm's-length debt. Journal of Finance, 47(4), 1367-400.

Ramirez, C. D. (1995). Did J.P. Morgan's men add liquidity? Corporate investment, cash flow, and financial structure at the turn of the twentieth century. Journal of Finance, 50, 661-678.

Sharpe, S. (1990). Asymmetric information, bank lending, and implicit contracts: A stylized model of customer relationships. Journal of Finance, 45(4), 1069-1087.

Stiglitz, J., \& Weiss, A. (1981). Credit rationing in markets with imperfect information. American Economic Review, 71, 93-410.

Tamowicz, P., \& Dzierzanowski, M. (2002). Biała księga nadzoru korporacyjnego. Gdańsk: IbnGR.

Van Ees, H., \& Garretsen, H. (1994). Liquidity and business investment: Evidence from Dutch panel data. Journal of Macroeconomics, 16(4), 613-627.

Wang, K., Wang, C. K., Lu, Q. (2002). Differences in performance of independent and financeaffiliated venture capital firms. Journal of Financial Research, 25(1), 59-80.

Weinstein, D., \& Yafeh, Y. (1998). On the cost of a bank-centered financial system: Evidence from the changing main bank relations in Japan. Journal of Finance, 53, 635-672.

Weller, Ch. (2001). The finance investment link in a transition economy: Evidence for Poland from panel data. Comparative Economic Studies, XLIII.

Williamson, O. (1988). Corporate finance and corporate governance. Journal of Finance, 43, 567-591.

World Bank. (2011). Doing business report 2011. Washington, DC.

\section{Author Biography}

Agnieszka Słomka-Gołębiowska, Ph.D. in economic sciences at the Warsaw School of Economics. Deputy Head of Industry Development Agency (Agencja Rozwoju Przemysłu), where she is in charge of ownership supervision. Also works as an assistant professor at the Warsaw School of Economics (Szkoła Główna Handlowa), conducting teaching and research activities related in corporate governance issues. 